\title{
Anxious Landscapes: From the Ruin to Rust
}

\section{Citation}

Picon, Antoine. 2000. "Anxious Landscapes: From the Ruin to Rust." Translated by Karen Bates. Grey Room 1 (September): 64-83. doi:10.1162/152638100750173065.

\section{Published Version}

doi:10.1162/152638100750173065

\section{Permanent link}

http://nrs.harvard.edu/urn-3:HUL.InstRepos:17932021

\section{Terms of Use}

This article was downloaded from Harvard University's DASH repository, and is made available under the terms and conditions applicable to Other Posted Material, as set forth at http:// nrs.harvard.edu/urn-3:HUL.InstRepos:dash.current.terms-of-use\#LAA

\section{Share Your Story}

The Harvard community has made this article openly available.

Please share how this access benefits you. Submit a story.

Accessibility 


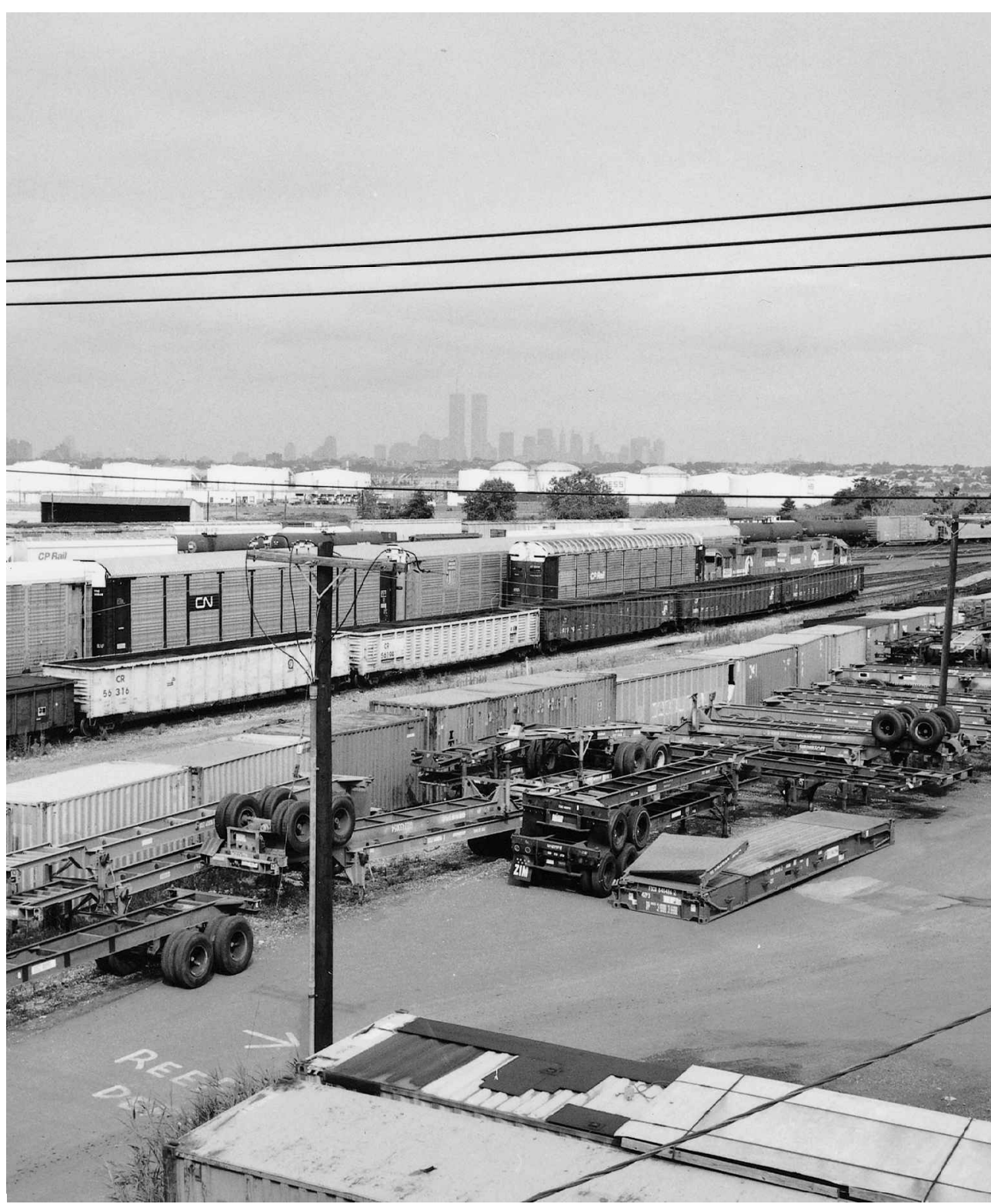

New York skyline,

seen from New Jersey.

Photo: Walead Beshty. 


\title{
Anxious Landscapes: From the Ruin to Rust
}

\author{
ANTOINE PICON \\ TRANSLATED BY KAREN BATES
}

\section{Introduction}

The traveler arriving at Newark airport-provided he is seated on the right side of the plane and the weather is good-notices the towers of Manhattan. In the late afternoon, as the sun reflects on the glass walls and reddens the brick partitions, it appears like a magic city made of crystal and porcelain, a city filigreed like a work of art, a transposition of the celestial Jerusalem dreamt up by the painters of the Middle Ages. But in front sprawls a sort of hell, or purgatory: cranes, immense bridges spanning platforms lined with containers, refineries and factories between which are creeping swamps, everything in poor condition and rusted out, as though irreparably polluted yet somehow endowed with a strange beauty. In their brutality, these "steps" to Manhattan create a landscape, a somewhat frightful landscape, but much more real in its crudeness than the distant sparkling of the Empire State and Chrysler Buildings.

Inspired by this kind of experience, which one can have in cities other than New York, I would like to start out with what may seem a fairly simple question: How is it that, turning our back on several centuries of tradition that generally associated the contemplation of landscape with the idea of a certain peace of mind, we are so often disconcerted, indeed even anxietyridden, by landscapes of this type? The fringes of Manhattan, with their infrastructures in ruin and their fragments of filthy land, make up just one case among many others of such disturbing landscapes.

Such a question emerges, one might imagine, in direct connection with that of technology, since we are not disturbed by views of untouched countryside. These are places where nature seems to have obliterated itself or at least yielded to man-made artifacts. In the same way that it does in New York, the entanglement of infrastructures and buildings that composes the periphery of European metropolises seems particularly perturbing. The entryways into big European cities like Berlin, London, and Paris, just to mention a few, are hardly more reassuring than those of their North and South American counterparts. 


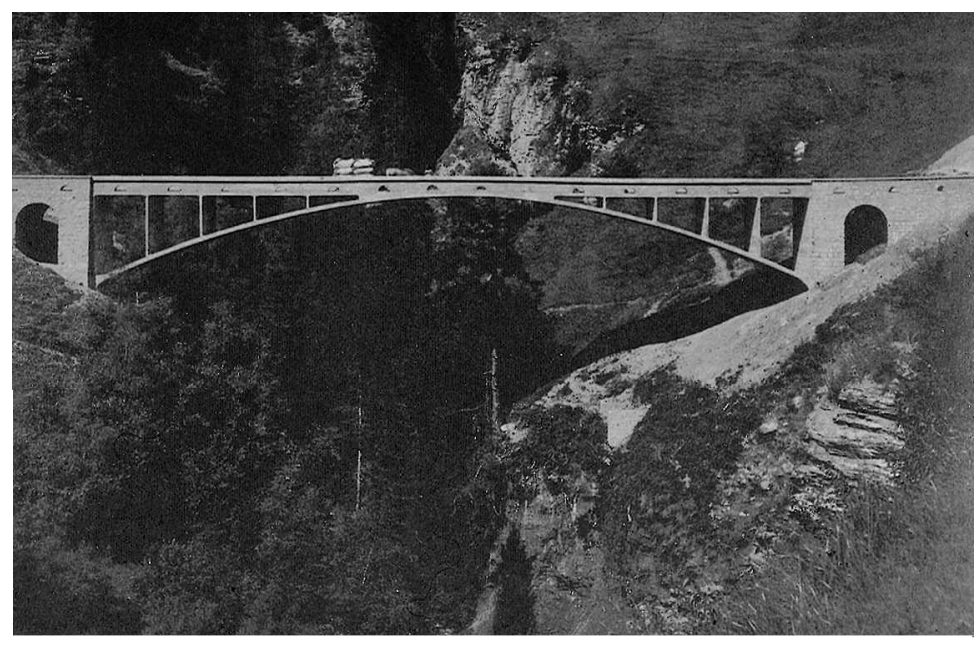

Left: Robert Maillart.

Valtschielbach Bridge, Donath,

Switzerland, 1925.

Opposite: Giambattista Piranesi. The Forum or Campo Vaccino, Vedute di Roma, c. 1761.

Although the preceding question was rather simple to formulate, the response to it will not be. It requires, in my opinion, the definition of a notion of technological landscape that distinguishes itself from that of traditional landscape on several points. The problem is most certainly caused by a landscape saturated by man's technological endeavors, a landscape where wild grass exists only between strips of asphalt, where abandoned warehouses and rusty carcasses replace Poussinesque ruins. It is a landscape that puts to shame the many evidences of the European landscape tradition, as it has long been defined in painting, as well as in the practice of gardeners, architects, and engineers.

\section{A Technological Landscape}

In traditional landscapes, whenever the works of man were present, they were nestled in the heart of nature. This immersion, incidentally, helped bestow upon them their true meaning as extensions of the natural world, not like a prosthesis, but rather as an instrument of revelation. Through the works of man, nature found itself simultaneously exposed, completed, sometimes even transfigured. Considered this way, human intervention presented numerous analogies with the art of the gardener who makes use of fabricated objects in a park in order to draw attention to its features and beauty. The temples and the pyramids of eighteenth-century English gardens almost always made reference to the undulations of the land or the presence of woods and water. ${ }^{1}$

Much like the objects within parks, bridges have long been a part of those kinds of constructions that came into their own only when in contact with a natural setting, with a site they were somehow meant to completeas if the rift or ravine were the petitioner of the crossing from the very start, as if the engineer were only ever an odd sort of gardener, working on a bigger scale and with a little less aesthetic refinement. ${ }^{2}$ What could be more representative of this relation between the work of art and its natural site than the bridges at Valtschielbach, Salginatobel, or Schwandbach by Robert Maillart, the fine arches of which seem to have been conceived to project against a background of rocks and greenery? ${ }^{3}$

In many cases, the relation between man-made constructions and nature is inverted, nature finding itself henceforth circumscribed, as if confined within mechanisms that no longer have anything to do with it. These cases correspond mostly to urban situations. In our developed soci- 


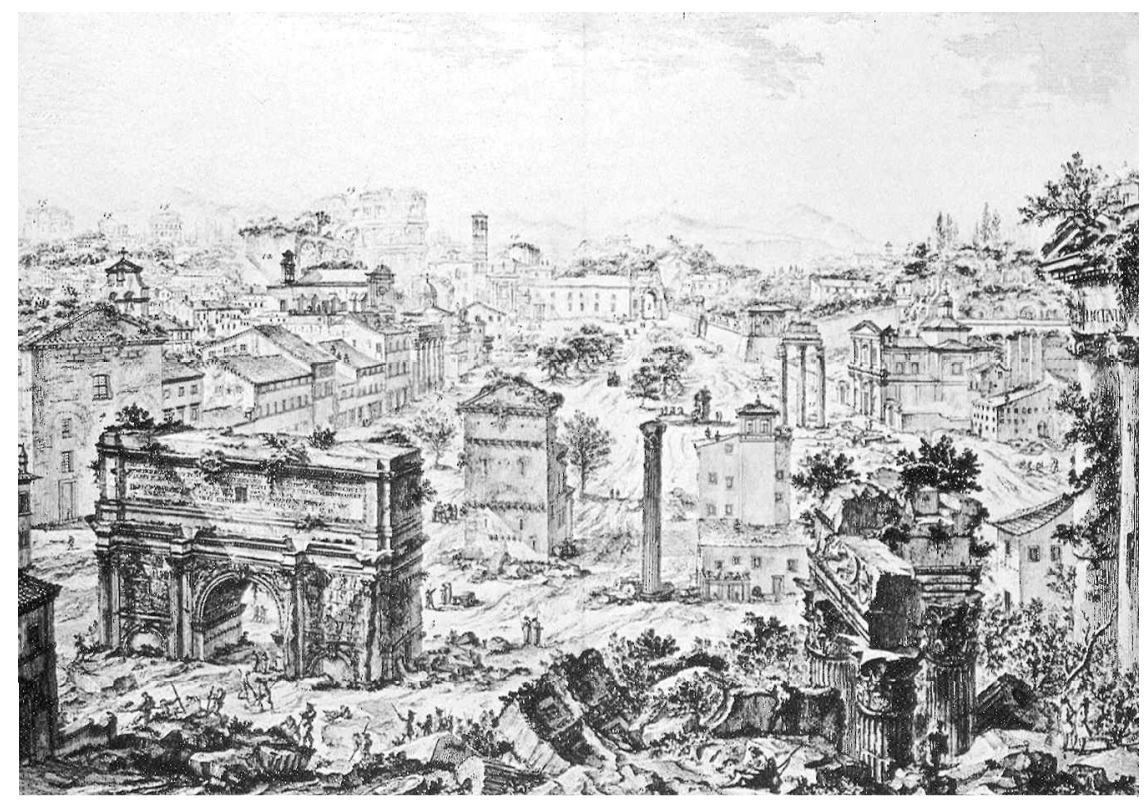

eties, the city constitutes the most primary of landscapes, the one we have most directly before our eyes. As the philosopher Fran ois Béguin noted, this inversion of the city as primary landscape arises at the dawn of the industrial revolution. ${ }^{4}$ The city stops being in the landscape, as a sort of monumental signature, to become, progressively, in and of itself, landscape. In less than a century, we go from the enclosed city profiled against the horizon of a fairly cultivated countryside, to the spectacle of the big city from which our eyes can no longer escape. Towers and spires shooting into the distance are replaced by the mobile play of streets and squares, the translucent and cavernous spaces of train stations and bazaars, the clashing of fa ades and the rolling of rooftops. City lights, signs, and street lamps furnish new material to painters. Chimney smoke blurs the angular outlines of brick and metal. The scenic interpretation of the city is successfully manifested in the work of the Impressionists, to which Oscar Wilde attributes "those wonderful brown fogs that come creeping down our streets, blurring the gas-lamps, and changing the houses into monstrous shadows." ${ }^{5}$ But its beginnings are already divulged in the work of Piranesi. In Piranesi's engravings, late eighteenth-century Rome takes on the likes of a fantastic landscape, with its antique ruins and baroque monuments, fragments of entablature, Latin inscriptions, and laundry that hangs from the windows of the houses.

If, as Fran ois Béguin observed, the Impressionists granted a new importance to the sky, "to the great tides of the atmosphere" that break against the rooftops of buildings, giving them a different appearance every hour, ${ }^{6}$ the architect Etienne-Louis Boullée offered another possible reference along the road that leads to the cityscape. Above Boullée's colossal public monuments-the cathedral, the monument to the Supreme Being, or the court of law, which he designed between 1780 and 1790 in honor of a regenerated humanity-the sky is in effect omnipresent, laden with clouds and mobile. ${ }^{7}$ Alongside Piranesi's Rome, Boullée’s equipped city announces a new era of urban landscape, one that borrows from nature only its variable skies. 


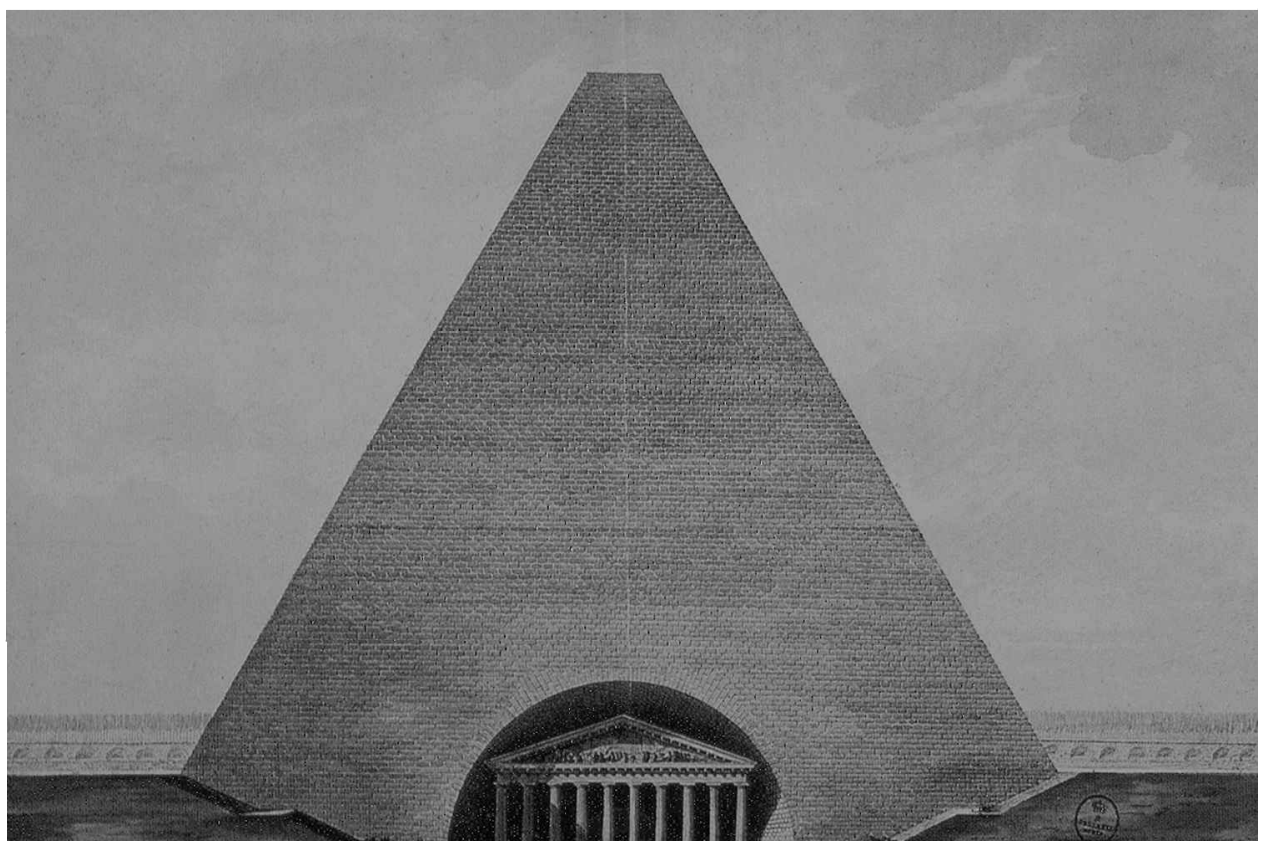

Since the time of the Impressionists, the city has become a landscape even more independent from the framework of nature. This process attains its climax today with the blurring of the boundary line between the city and the surrounding territory. In many cases, the city seems to have absorbed the countryside around it; it seems to have made itself master in order to form with the countryside an amalgamation of a new type. Within this amalgam, infrastructures and technical equipment have obtained a much larger importance than in the era when the sewage system was still considered a novelty. Like Queen Victoria's London, the Paris of Napoleon III and his immediate successors was still dependent upon simple and crude technologies. From the sewers to the subway's corridors, the networks retained a thickness quite different from that of the thousands of slender, invisible wires that run under the roadways of our contemporary urban agglomerations. In our cities, the large infrastructures have not disappeared; rather technology has penetrated everywhere beneath the cement piles and piers of buildings and highways. Technology, sliced more and more finely, or in the form of cables, constitutes the veritable web of an urbanity that continually resorts to it, whether for getting around town or withdrawing cash, for heating or for distraction.

As technology winds underneath sidewalks and between the partitions of buildings, it gives birth to an entire set of urban "furniture," whose very presence is haunting, whether in the form of billboards or road signs, video screens, dividers, gates, or railways. Between the massive infrastructures of the big city and the networks of fiber optics, this technological "furniture" begins to saturate the space. In the city, technology is present on all scales with the same intensity and the same complexity. There are almost as many knots and connections in the electronic circuits of an ATM as in the road system of the neighborhood in which it is located. Like the city, contemporary technology possesses a fractal character. ${ }^{8}$

Can this over-equipped city that surrounds us still be considered a landscape, even with the aesthetic connotations attached to this term? Isn't the 
city more about a faceless environment, like certain of the networks that innervate it and that seem unamenable to any idea of representation?

Perhaps the criterion of double artialisation advanced by the philosopher Alain Roger in order to clarify the notion of landscape, allows for a response to this question. ${ }^{9}$ According to Roger, landscape is born of a double movement: of apprehension of the environment and of interpretation of the characteristics of that environment through the resources of art. The aesthetic of landscape resides thus in the imbrication of visual perception and culture.

Such an imbrication is mirrored in the glance, filled with anguish, that we cast upon the contemporary city. Even more than the traditional countryside, the city is an environment consisting of the work of man, and this work carries the mark of visual considerations. In fact, nothing could be more false than to assert, as one often does, that today's city testifies to a total indifference with regard to form and ambiance. On the contrary, from building fronts to billboards, almost everything is designed and seeks to attract and seduce the eye. ${ }^{10}$ The chaotic character of the large, contemporary cityscape originates more from an over-abundance of aesthetic intentions than from their radical absence. These intentions interfere with each other because they each belong to very different registers. The effectiveness of an advertisement, for example, often prevents it from blending into the environment that surrounds it. Added to the incoherence borne of a diversity of visual registers is the phenomenon of accelerated aging. Within the contemporary city, the new and the less new seem separated by a distance more difficult to cross than the gap between a Gothic cathedral and a Neoclassical château.

Certain spaces seem nevertheless thoroughly devoted to utility; the edges of Manhattan across the river in New Jersey are of this type. But these spaces find themselves curiously invested with a more heightened possibility, one that possesses a stronger poetic value than the more heavily policed urban order. Doubtless because they appear as the heirs of the shores and quays of an earlier era, the platforms of containers and the borderlands of countries offer more fodder for dreams than do housing tracts and shopping malls. In any case, contemporary art has taken possession of them, just as painting and poetry at one time secured the countryside. Yet, with regard to the landscape tradition, a shift has nevertheless taken place. Photography has largely replaced painting; movies and video games have replaced poetry. It would seem, therefore, that traditional artistic forms meet with some difficulty in portraying the kind of anxiety to which today's technological landscape gives rise. 


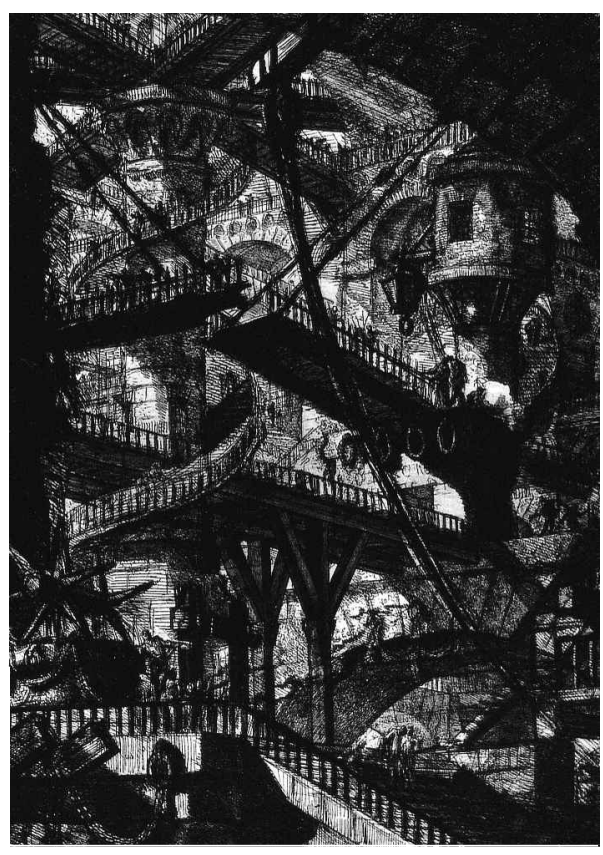

Giambattista Piranesi.

Carceri, plate VII, state 4

c. $1770-1835$.

\section{Landscape and Anxiety}

Although the tradition of Western landscape preferred to place itself under the protection of pleasant stereotypes, it always contained images that escaped them-representations of hell, deserted lands where the Devil comes to tempt Saint Anthony, apocalyptic scenes, as in Brueghel's The Triumph of Death, paintings of epidemic in the baroque age, or the aftermath of nineteenth-centurybattles. In these anguish-ridden, even fearsome, landscapes, action generally prevailed over setting. More than the threatening skies, stormy atmosphere, jagged rocks and raging sea, it was the postures, expressions and gestures of the characters that impacted upon the spectator. Everything transpired as if the action was rubbing off somehow on its environment, coloring it with the exact nuance that it presented, whether it was merely disturbing or downright dramatic. This environment constituted at the same time a scenery. It would suit our purpose to study more closely the stage decoration of seventeenth- and eighteenth-century theater and opera in relation to the topic of anxiety. These were the decors that Nicolas Le Camus de Mézières gave as examples to the architects of the 1780s so that they would put more character into their works. "[W]e have only to look at our stage decorations, which use the mere imitation of works of Architecture to govern our affections," writes Le Camus at the beginning of his Genius of Architecture, before evoking "the abode of Pluto [which] strikes horror and dread into our souls." 11 In theater and opera decoration, as in painting, action was always the principal source of spectator emotion.

Praised by Le Camus, the représentations en machines produced by Servandoni at the Tuileries Theater in the 1740s possibly indicate a turning point. These were sequences of scenes without characters where one could see, for example, "The Camp of Godfrey . . . parched by the fires of the Dog days: almost no shadow, a reddish sky, an arid earth, an effect of light that suggested flames in the air."12 The setting tended to emancipate itself from the intrigue. But just because the absence of characters appears provisional-as if the actors had just left the scene only to reappear again shortly, thereby allowing the drama to start up again-does not mean that the emptiness established in their wake does not take on a new significance.

This significance becomes even clearer in Piranesi's engravings of the Carceri. In these prisons, the landscape is entirely constructed; it presents almost no glimpse of the exterior world or natural objects. At the center of this landscape, action becomes secondary. The sufferings we imagine and 
the whisperings we believe we hear with our ears pressed to the walls, seem like a product of the architecture, an architecture in which the artist takes pleasure in multiplying the perspectives in order to mislead the spectator. This architecture causes anxiety due to its potentially limitless character, one that turns it into a synonym for imprisonment-a stifling imprisonment. It is also anxiety-producing because, in making human action secondary, without referring at all back to nature, it raises the question of death. Everything happens as if the architectural framework had become a machine to crush people.

Piranesi's Carceri mark the emergence of a new kind of representation of landscape, a representation that will be used frequently from that time forward to give vision to the big city or metropolis. To convince ourselves, it is enough to think about Gustave Doré's engravings of London, with their little basement window lights and gloomy walls. ${ }^{13}$ Beyond Impressionism and its positive vision of the city, the Carceri seem to announce, like a sort of inaugural nightmare, two essential characteristics of the contemporary technological landscape: its absence of clearly marked limits and the relativization of the meaning of human action toward which it drives. Even today, the impression of imprisonment and the feeling of death are two dimensions common to the relationship we maintain with this landscape.

\section{A Feeling of Imprisonment}

The feeling of imprisonment also has a history. On the brink of the eighteenth and nineteenth centuries, at the same time as the city transforms itself into landscape, the earth manages to restrict itself in order to become the finite planet we know today. The terra incognita, the blank zones that the cartographers of the Renaissance filled with supernatural people and animals, seem to fall off the edges of the world map. By the years 1820-1830, the Saint-Simonians could already conjure up the global management of the planet by means of roads, canals and railways. ${ }^{14}$ Conceived on the scale of intercontinental navigation, the Suez and Panama canals testify to the success achieved by this planetary vision.

A new stage in the closing of the world is entered with the Cold War and the beginnings of space exploration. ${ }^{15}$ While radar is made to scrutinize the sky in search of airplanes or missiles and the first satellites are placed into orbit, we grapple with the modeling of phenomena like the depletion of natural resources-a main concern for organizations like the Club de Rome. The 1950s and 1960s see the accelerated development of a systemic analysis that Buckminster Fuller proposes to apply to the entirety of the planet in his World Game, a mixture of interactive simulation and 


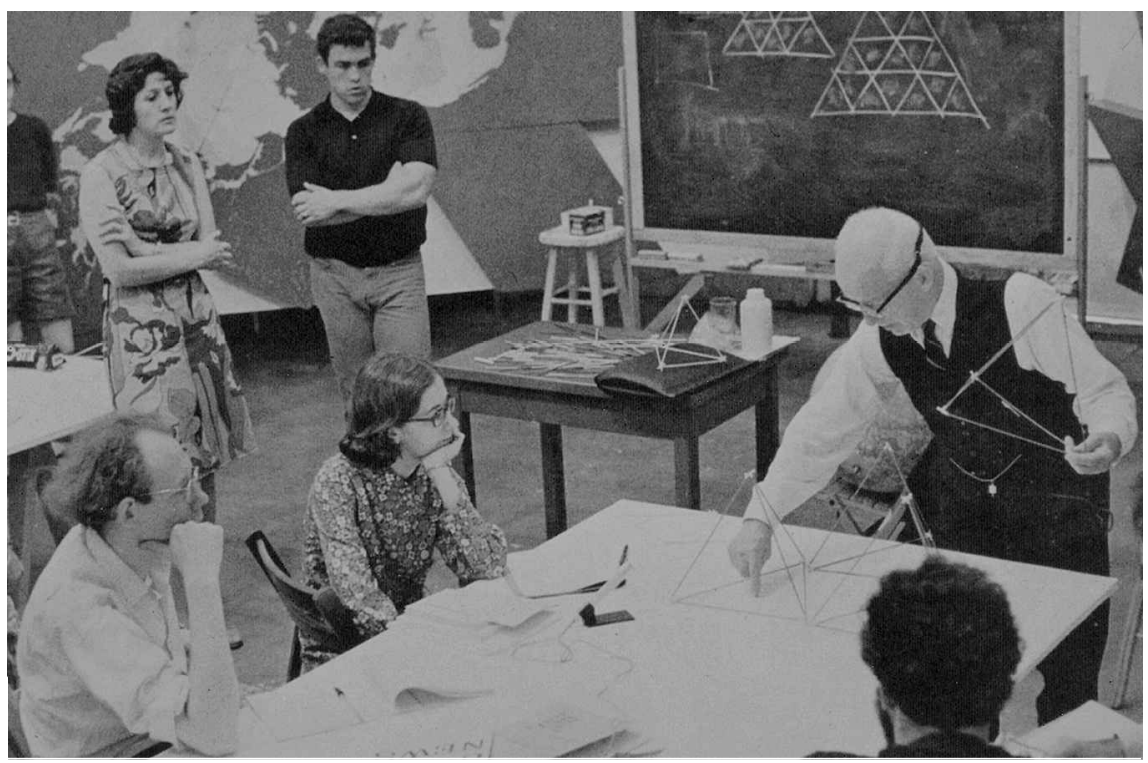

role-playing intended to enlighten thousands of students about the stakes of what we would today call "sustainable development." ${ }^{16}$ In book after book, Fuller compares the earth to a space ship aboard which humanity finds itself trapped. ${ }^{17}$ The feeling of vulnerability suggested by this image would soon be confirmed by views of the earth obtained by the Apollo expeditions. The blue ball seen outlined above the lunar horizon appears very small and fragile in relation to the immensity of interstellar space.

The enclosure of the world seems finally to be completed before our eyes with the globalization of the economy. In the wake of the establishment of intercontinental economic giants, a web of insignias like McDonald's fills up the space and renders its contraction even more noticeable.

In contrast to the planet, however, the city tends to become boundless, blending into territory. It is no longer possible to contemplate it from the outside, except perhaps from strategic command centers where one might envisage its destruction by means of atomic bombs. The urban landscape is no longer framed. Here again, this absence of borders constitutes a rupture with the Western landscape tradition, which used to depend invariably on a pictorial framing. Subsequently, we understand better how photography or cinema interprets the contemporary urban landscape more readily than does an art such as painting. The framings that they propose have a greater capacity for instability, and this instability resonates well with that of a limitless landscape.

In addition to the absence of limits, the preponderance of artifacts over natural objects constitutes another characteristic of the contemporary urban landscape. Within this landscape, nature itself seems fabricated, whether it exists in the form of green space, natural preserves, or fallow land. The discovery made by Jean Follain- - One day I sensed that beneath the pavement of Paris there was earth, the old earth of landowners and collectivists" ${ }^{18}$-is not really applicable anymore. The polluted earth that pushes up between the pipes, tubes and cables when the asphalt is ripped up looks like interstitial tissue or manmade landfill. The absence of a natural vista leads to the same sensation of imprisonment as the global devices of war and commerce. 
In this landscape, technical objects tend to lose their autonomy.$^{19}$ In fact, there is no nature worthy of the name left to oppose. Instead of being faced with traditional machines like the locomotive or the automobile, we find

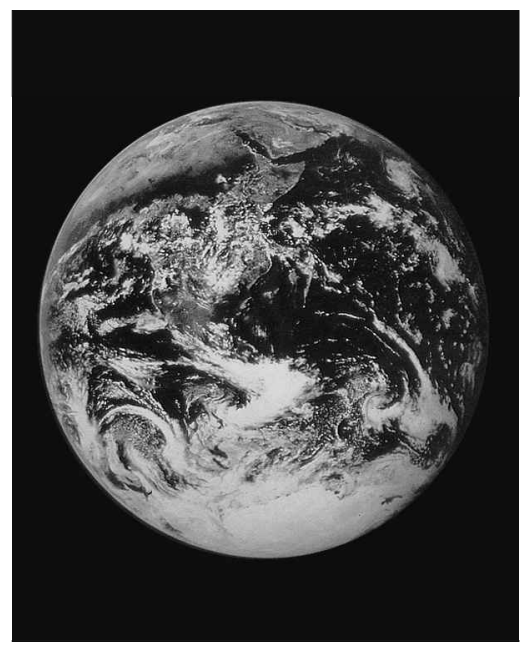
ourselves more and more in contact with a world of quasi-objects, of terminals, connectors and networks. These latter no longer possess the individuality that philosophers like Gilbert Simondon once attributed to technical objects. ${ }^{20}$ As if to echo this new reality, English-speaking historians of science and technology talk readily of the "seamless web" of contemporary technology. ${ }^{21}$ The absence of perceptible seams does not, however, mean that the contemporary technological landscape is without fractures. Whether at the planetary or national level, the Internet alone reflects the imbalances of economic and social development. ${ }^{22}$ More generally, in following the lines and folds of the social body like both a tight-fitting and creased garment, tight and creased to the point of rupture, technology and the city seem to organize themselves around thresholds and edges too numerous to count. But these striations do not form an articulated system; they appear rather like a veil, analogous to those often complicated background screens against which the icons of computer applications and data processing files stand out. In other words, technology and the contemporary city are simply discontinuous. Yet they appear at the same time to be sheets of cloth from the same bolt.

These sheets flicker in direct relation to their complexity. Instead of organizing itself around easily identifiable figures, the urban landscape of today seems more a matter of textures and lights. This is most likely the reason that architects like Jean Nouvel claim to be fascinated by these dimensions of the urban experience. In a series of articles and interviews published a few years ago, Nouvel went so far as to prophesize the end of that three-dimensional architectural space which claims its roots in the Modern Movement and the return to an architecture that plays upon the effects of partitions, grain and transparency. ${ }^{23}$

This world of textures and lights brings us back once again to computer terminals. It also maintains obvious links with the question of immateriality and virtual space. Although sometimes presented as a sort of liberation, the extension of the real city by cyber-spaces nested one inside the another is not necessarily synonymous with freedom. Among recent films, The Matrix is certainly the one that plays the most distinctly upon the ambiguity of the virtual. Instead of allowing its characters to escape from their slavery in a world of machines, the giant simulation imagined in the film keeps them in chains. In order to find one of the most gripping expressions of the 


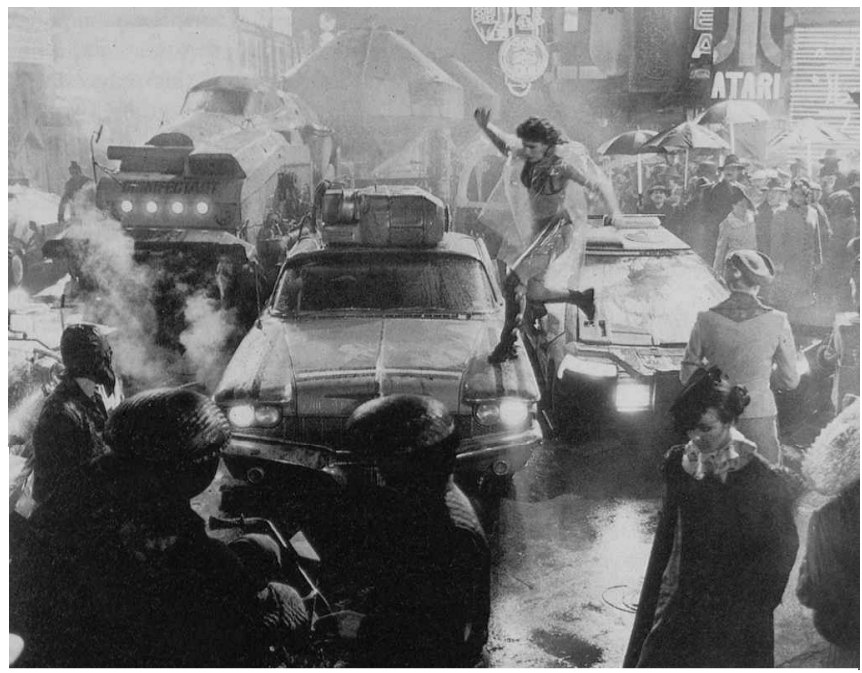

Left: Blade Runner. Dir. Ridley

Scott, 1982. Street scene.

Opposite: Robert Doisneau.

Photograph for DATAR, c. 1985.

contemporary anxiety of imprisonment within gigantic conglomerations, however, we have to return to an older film. In Ridley Scott's Blade Runner, the hero tirelessly paces the streets of a city that simultaneously resembles Los Angeles and Tokyo, New York and Teotihuacan. A veritable summary of the world, a world too dense and too old, without nature or redemption, the city of Blade Runner has almost all the attributes of a prison. It is only at the very end of the film that its two main characters manage to escape, and then only in the short version of the film where the "happy ending" was demanded by the producers.

\section{Obsolescence and Death}

As soon as one moves away from the central district, contemporary photography and film present today's big city as a "territory of emptiness," to employ the term used by Alain Corbin to describe the seaside before its appropriation by nineteenth-century Europe. ${ }^{24}$ The characters that wander this territory seem somewhat out of place there. The city appears like the kind of world that would normally exclude humans. For the French this tendency manifested itself, for example, in the photographic investigation performed on behalf of DATAR (Délégation à l'aménagement du territoire et à l'action régionale) in the early 1980 s. $^{25}$ Traversing the residential suburbs and industrial areas of the France of the Trente glorieuses, a France that had undergone a modernization accelerated by the technocracy of de Gaulle and Pompidou, the photographers appointed by DATAR brought back strange images of deserted streets and squares, abandoned parking lots, indistinct terrain and lands as empty as the European coasts of the modern period, with their few, scattered fishermen haunting the rocks like silhouettes in the far-off background of a painting. Such emptiness is filling up, however, with very precise areas devoted to circulation, consumption and mass recreation. The shopping malls and theme parks are teeming with people. Like the sea evoked by Corbin in Le Territoire du vide, the sea that we fear and onto which we will only venture if necessary, the contemporary city brings to mind a desert plowed by boats going from one overpopulated port to another.

It is striking to find this opposition between absence and saturation once again in the brochures of new French cities. Whether it is CergyPontoise or Marne-la-Vallée, we see a succession of rational, empty spaces punctuated by views of thoroughfares devoted to commerce and large, overpopulated surfaces. Because the presence of people in crowds seems 


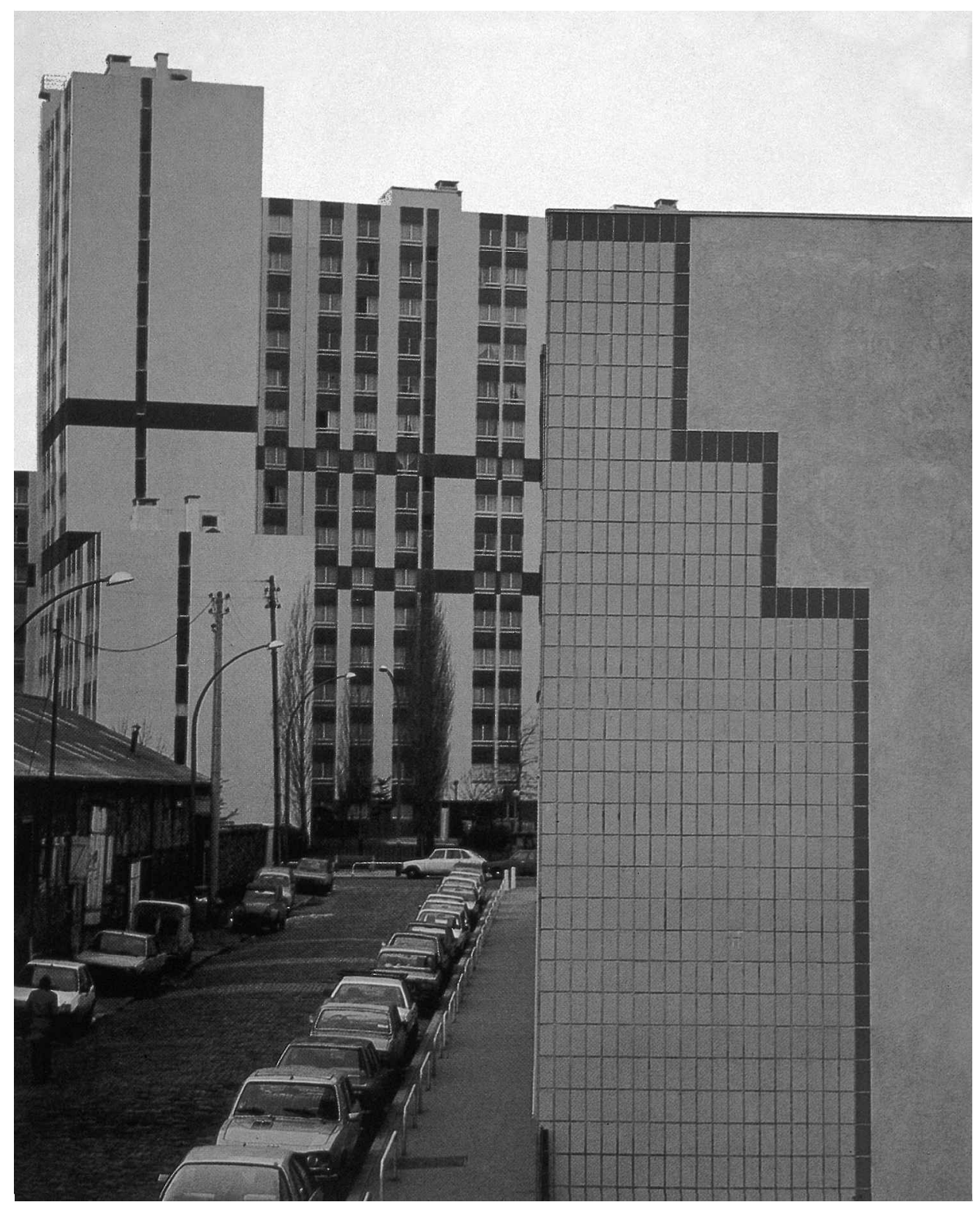

justified only in the name of consumption, the city is a matter of merchandise, of leisure or of cultural or sporting events. Like shopping centers, stadiums are frequently full. The "territory of emptiness" of the big city is also a territory of consumption. The contrasts that structure this territory are incarnated, consequently, in the face-off between two places invested with a strong emotional force: the shopping center and the garbage dump. It is between these two poles that entire sections of the contemporary urban experience are organized. Buy and throw away: this elementary cycle marks the rhythm of the days and weeks. In a city without perceptible limits, completely devoted to mass consumption and its consequences, the contrast between commercial spaces and garbage dumps might well have replaced - on a level more symbolic than real, of course-the old opposition between center and periphery.

Framed this way, the cityscape could never leave us indifferent. It is 
impossible to maintain that distance, even if fictitious, between the spectator and the scene he is contemplating that the Western landscape tradition presupposed and that was theorized by Kant at the end of the eighteenth century. ${ }^{26}$ In contrast to the townspeople dreamed of by Kant, who enjoy their country view, it is impossible for us to detach ourselves from the thousand and one gestures that connect us to the urban landscape in front of our eyes. We have all too often purchased things there before throwing them away. The packaging and greasy papers follow us wherever we look, wherever we step.

The implication of all of these moments does not arise from an intention, nor even from a clearly affirmed end or finality. It is also in this sense that the city is endless (sans fin), in the manner recently emphasized by JeanLuc Nancy. In his opinion, it is the absence of finality that most accurately brings together the city and technology, that makes it "like an assembling and an expression of the essence of technology."

Such is the technical truth, [adds Nancy,] to clear the way in every direction without a final calling, to open the comings and goings of events rather than advents. Things and people, words and acts, are not disposed towards finishing and then erasing their traces, but rather towards starting again, getting back into movement, passing again through the passages, the operations, divisions, exchanges and combinations, in the impetuses that come from everywhere and end up nowhere but at another invention in the journey, through houses and palaces, churches and hotels, always by the streets and by the highways. ${ }^{27}$

Technological even in its folds, circulatory, the landscape of the city paces itself more and more to the rhythms of mass consumption. At the same time, it takes on a definite functional coloration. Even in the absence of an overall finality, most of the elements of its composition-infrastructures, buildings, billboards-were conceived with a very precise goal in mind.

That which works wears itself out and stops being useful. And everything wears itself out, or almost, in the cityscape of today. Metal oxidizes, plastic yellows and cracks. The idea of functionality goes hand in hand, therefore, with that of obsolescence. Obsolescence is not exactly the same thing as death, the progressive and dignified death that came to the objects of yesteryear. In traditional landscapes, the productions of man, his constructions in particular, surrendered themselves progressively to nature in the form of the ruin. The ruin reintegrated, in successive stages, the 
traces of human activity into the cycles of nature. There is nothing of the sort in the contemporary city, where objects, if they don't disappear all in one go, as if by magic, are instead relegated to obsolescence, a bit like the living dead who endlessly haunt the landscape, preventing it from ever becoming peaceful again. We have gone from ruin to rust, from trace to waste.

The nineteenth century had already seen the premonition of this degradation. In the work of the most vehement critics of the machine age, John Ruskin and his principal disciples in particular, this degradation often gave birth to the utopia of a return to the values of the pre-industrial world.$^{28}$ Perceived as respectful of materials, of the craftsman's know-how, and of the cycles of nature, this world gave rise to a growing nostalgia, even in the presence of an increasing number of new materials and machines.

We hear the weakened echo of this nostalgia in the work of Auguste Perret-rarely suspected of hostility towards the technologies of his timewhen he opposed the Parthenon and the locomotive in response to Violletle-Duc, who had exalted the latter's style in his Lectures on Architecture.

The locomotive, for example, has a special physiognomy which all can appreciate, and which renders it a distinct creation. Nothing can better express force under control than these ponderous rolling machines; their motions are gentle or terrible; they advance with terrific impetuosity, or seem to pant impatiently under the restraining hand of the diminutive creature who starts or stops them at will. The locomotive is almost a living being, and its external form is the simple expression of its strength. A locomotive therefore has style. ${ }^{29}$

Going beyond Viollet-Le-Duc's position, Perret's critique took aim at Le Corbusier and his famous parallel, drawn in Towards a New Architecture, between the Parthenon and the Delage "Grand-sport" automobile. ${ }^{30}$ Apostle of concrete and modern construction, Perret could not help but feel worried when faced with the unyielding mechanized future that his young colleague predicted for humanity. Perret declared in 1924:

In a work of art, it is necessary to consider character and style. Character is the manner in which the work responds to its destination, it is the rapport, the relation between the object and its end. Style is the art of using materials to which the work bears witness, and of obtaining from them the maximum harmony. A locomotive 
has only character. The Parthenon has character and style. In a few years, the most beautiful locomotive of today will be but scrap metal. The Parthenon will sing eternally. ${ }^{31}$

In the years 1920-1930, from Le Corbusier to Perret, the perception of the modern environment is already oscillating between the intoxication provoked by its functional character-source of an abstinence more authentic than the stylistic affectations of a system of beaux arts on the decline-and the fear of breakdowns and obsolescence. In the sense that it is likely to stop working the way the locomotive did, does the modern environment have a meaning?

However hostile to modern architecture and its debates, the Nazi aesthetic also carries the mark of this tension between the intoxication of effectiveness and the fear of obsolescence. Albert Speer testifies to this in a passage from his Spandau Diary where he contrasts the unspoiled beauty of nature to "the unavoidable ugliness of the technological world."

Now, evening in the cell, I have been thinking back on the regime's interest in beauty, which in fact was very marked. The ruthlessness and inhumanity of the regime went hand in hand with a remarkable feeling for beauty, for the virginal and unspoiled, although that feeling quite often degenerated into the sentimentality of a postcard idyll. Today I sometimes read statements to the effect that all this was merely camouflage, a calculated maneuver to distract the attention of the suppressed masses. But that was not so. Of course the regime's craving for beauty also had to do with Hitler's personal taste, with his hatred for the modern world, his fear of the future. But there was also an unselfish social impulse at work, an effort to reconcile the unavoidable ugliness of the technological world with familiar aesthetic forms, with beauty. Hence the ban on corrugated iron roofing for farm buildings, hence Autobahn maintenance buildings in halftimber style, hence birch woods and man-made lakes at army camps. As chief of the Beauty of Work Office I was responsible for a part of this program, and I still take unabashed satisfaction in what we accomplished. ${ }^{32}$

We have not completely freed ourselves from nostalgia for inviolate beauty, nor from the regret experienced before the ugliness of certain aspects of our technological environment. Given some distance, the solution of disguise and pastiche proposed by Speer reveals its insufficiencies. The "unabashed satisfaction" of Hitler's Secretary of State is not only 
shocking with regard to the atrocities from which it is inseparable, and which it passes over in silence; it also appears totally unsuited to the problem at hand. Instead of fighting the uneasy feeling caused by technological devices, the "Autobahn maintenance buildings in half-timber style" only reinforce their artificial character. Dressed up in rags from an older world, the contemporary technological environment seems even more vulnerable to the process of obsolescence.

Why does rust frighten us so while the ruin is adorned with a reassuring character? It is very probably necessary to begin by replying to that question before we attempt to wrestle with "the inevitable ugliness of the technical universe." The ruin, as we have said, restores man to nature. Rust, on the other hand, confines him in the middle of his productions as if within a prison, a prison all the more terrible since he is its builder. Who other than he has built these cities which he practically never leaves anymore, these networks that keep him attached to his television or computer screen? The simple perspective of a destiny of this kind reveals what is inhuman in the work of man. The biggest fear suggested by the contemporary technological landscape is that of the death of humanity in the midst of the signs of its triumph over nature.

Science fiction films describe this death to us in at least two different ways: extinction of the catastrophic sort, or extinction of a more insidious variety, in which a progressive denaturation of man occurs. The disappearance of the ozone layer on one side, the mechanization of man or his instrumentalization by means of genetic manipulation on the other-such are the two types of scenarios that haunt us. In the first instance, man and humanity disappear together. In the second, man witnesses himself being progressively dehumanized. He becomes an insensitive machine, capable of the worst monstrosities. When perceived negatively, the cyborg-that amalgam of flesh and machine that recurs frequently in science fiction novels and films-constitutes one of the most extreme expressions of this second alternative. ${ }^{33}$

\section{A Re-enchanted World}

Nothing forces us, however, to envisage the becoming-cyborg of humanity as the shipwreck of civilization. More generally, it may very well be that the anxious character of many contemporary landscapes is the indication of profound transformations affecting the definition of the subject who contemplates them, without such transformations necessarily being synonymous with the irremediable degradation of the human condition. After all, this is not the first time that the look that we cast over our surroundings 
has been modified. Each time, such a transformation proves inseparable from a mutation of the ideal image we project of ourselves. When the categories of vision changed radically at the dawn of the Renaissance, for example, and perspective was invented, the figure of the modern man emerged to replace that of the faithful of the medieval period. Instead of embodying irretrievable degradation, the cyborg could well represent a new avatar of this ideal creature, this fiction that serves us simultaneously as reference and project.

Without resolving this new image that is about to be added to the long series of those that have allowed man to define himself and to act upon himself and his environment, one cannot help but be struck by the extent of the mutations that already affect the categories of vision. We see much further and much higher than our predecessors. Shortly after having invented perspective, Renaissance man was elevated by thought above his principal cities in order to portray them. ${ }^{34}$ With the aid of satellites, we can now observe the entire earth like a tapestry of varied motifs. At the other end of the optic scale, we are now capable of observing even the most tenuous of phenomena, such as crystallizations and microfissures. We can be much more nearsighted, and, as Pascal suggested in his Pensées with his reflections on the two infinities, ${ }^{35}$ there are entire worlds that reveal themselves to us in the folds of matter.

At the two extremities of this range of possible viewpoints, familiar forms seem to give way to luminous effects-scintillations, iridescence, reflections-as well as to textures often based upon contradictory impressions like smoothness, glossiness, or graininess. Configurations, both immediately perceptible by the senses and more abstract, substitute themselves for the contours of the world that is familiar. Seen by satellite, Los Angeles doesn't look much different from a section of matter observed in a microscope. The importance of the dominion of lights and textures in the contemporary technological landscape could well originate from this transformation in the categories of vision. Such a transformation leads us to suspend, if only provisionally, questions such as those of "far" and "near." Who tells us that it's Los Angeles we're contemplating, instead of a piece of sidewalk?

Rendered somewhat abstract by its functional character, the contemporary urban landscape is organized according to textures that owe more to woven design than to form in a traditional sense. It is perhaps this relationship with a universe more textile than sculptural or architectonic that remains for us to investigate and cultivate.

The abstract motifs that compose this landscape confer on it something 
mysterious, even magic. Like cyborgs and other intelligent robots of science fiction, new, fantastic creatures haunt its dark avenues forever after. We are possibly on the eve of a re-enchantment of the world. To live in an enchanted world, however, is not necessarily synonymous with ease. The people of the Middle Ages developed in a world populated by angels and demons, magic forests and supernatural animals. Yet this world was at the same time hard and cruel: in fairy tales, the children are almost always afraid and Tom Thumb is at the point of being eaten. No doubt it is for this reason that we feel at times lost and distressed in the middle of our cities, cities as large as the ogre's house. 
Notes

1. See for example, Monique Mosser and Georges Teyssot, eds., The Architecture of Western Gardens: A Design History from the Renaissance to the Present Day (Cambridge: MIT Press, 1991).

2. See the articles assembled in Antoine Picon, ed., L'Art de l'ingénieur: Constructeur, entrepreneur, inventeur (Paris: Editions du Centre Georges Pompidou and Editions du Moniteur, 1997).

3. See David P. Billington, Robert Maillart and the Art of Reinforced Concrete (Cambridge: MIT Press, 1989).

4. Fran ois Béguin, Le Paysage (Paris: Flammarion, 1995), in particular 19-20.

5. Oscar Wilde, "The Decay of Lying” (1890) in Richard Ellmann ed., The Artist as Critic: Critical Writing of Oscar Wilde (Chicago: University of Chicago Press, 1982), 312. Passage cited in Alain Roger, Court traité du paysage (Paris: Gallimard, 1997), 13-14.

6. Béguin, Le Paysage, 20.

7. Jean-Marie Pérouse de Montclos, Etienne-Louis Boullée (Paris: Flammarion, 1994).

8. On this fractal character of the contemporary city and technology, see Pierre Veltz, Mondialisation, villes et territoires: L'Economie d'archipel (Paris: P.U.F., 1996); Antoine Picon, La Ville territoire des cyborgs (Besan on: Les Éditions de l'Imprimeur, 1998).

9. Roger, Court traité du paysage, $16 \mathrm{ff}$. This criterion draws in part from analyses formulated in Augustin Berque, Les Raisons du paysage: De la Chine antique aux environnements de synthèse (Paris: Hazan, 1995).

10. On the aesthetic ambitions of "urban commercialism," see for example Marc Emery and Patrick Goulet, "Le Vernaculaire commercial a-t-il une âme?" in L'Architecture d'aujourd'hui 318 (September 1998): 86-93.

11. Nicolas Le Camus de Mézières, The
Genius of Architecture; or, the Analogy of That Art with Our Sensations (1780), trans. David Britt (Santa Monica, Cal.: Getty Center for the History of Art and the Humanities, 1992), 71.

12. Le Camus, The Genius of Architecture, 71.

13. See Phillipe Junod, "Babylone-surTamise : Londres vue par Gustave Doré,” in Le Temps de la réflexion, vol. 8: "La Ville inquiète,” (Paris: Gallimard, 1978), 61-77.

14. On Saint-Simonism, the fundamental works are Sebastien Charléty, Histoire du saint-simonisme (1825-1864) (1896; reprint, Paris: P. Hartmann, 1931); HenryRené D’Allemagne, Les Saint-simoniens 1827-1837 (Paris: Gründ, 1930).

15. See Paul N. Edwards, The Closed World. Computers and the Politics of Discourse in Cold War America (Cambridge: MIT Press, 1996).

16. On the World Game, see Mark Wigley, "Planetary Homeboy," ANY Magazine 17 (1997): 16-23.

17. The metaphor reaches its culmination in R. Buckminster Fuller, Operating Manual for Spaceship Earth (Carbondale, Ill.: Southern Illinois University Press, 1969).

18. Jean Follain, Paris (1935), reprinted in Mary Feeney and Louise Guiney, trans., Selected Prose, Jean Follain (Durango, Colo.: Logbridge-Rhodes, 1985), 9.

19. On this theme, see Picon, La Ville territoire des cyborgs.

20. Gilbert Simondon, Du Mode d'existence des objets techniques (1958; reprint. Paris: Aubier, 1989).

21. The problem at the origin of the expression is clearly explained in Wiebe E. Bijker, Thomas P. Hughes, and Trevor J. Pinch, eds. The Social Construction of Technological Systems (Cambridge: MIT Press, 1987).

22. Africa, for example, is the continent the least served by the Internet, as it is by the more traditional network systems. 
23. Jean Nouvel, "A Venir," in L'Architecture d'aujourd'hui 296 (1994): 50 ; Jean Nouvel, lecture given at the Centre Georges Pompidou in 1992, Dépliant 1 (1994).

24. Alain Corbin, Le Territoire du vide: L'Occident et le désir du rivage 1750-1840 (Paris, 1988); The Lure of the Sea: The Discovery of the Seaside in the Western World, 1750-1840, trans. Jocelyn Phelps (Cambridge: Polity, 1994).

25. Paysages, photographies. (Paris: Mission photographique de la DATAR, Hazan, 1989).

26. See for example Bernard Bourgeois, "L’Idéalisme allemand devant la beauté naturelle et l'embellissement de la nature," in Mort du paysage ? Philosophie et esthétique du paysage, ed. Fran ois Dagognet (Seyssel: Champ Vallon, 1982), 161-177.

27. Jean-Luc Nancy, La Ville au loin (Paris: Mille et une nuits, 1999), 47-48.

28. See Philippe Jaudel, La Pensée sociale de John Ruskin (Paris: Marcel Didier, 1973); Paul Meier, William Morris: The Marxist Dreamer, trans. Frank Gubb
(Atlantic Highlands, N.J.: Humanities Press, 1978).

29. Eugène-Emmanuel Viollet-le-Duc, Lectures on Architecture, vol. 1, trans. Benjamin Bucknall (New York: Dover Publications, 1987), 184.

30. Le Corbusier, Towards a New Architecture(1923), trans. Frederick Etchells (New York: Holt, Rinehart and Winston, 1976), p. 125.

31. Cited in Roberto Gargiani, Auguste Perret: La Théorie et l'œuvre, trans. Odile Menegaux (Paris: Gallimard, 1994), 89.

32. Albert Speer, Spandau: The Secret Diaries, trans. Richard and Clara Winston (New York: Macmillan, 1976), 399.

33. See Picon, La Ville territoire des cyborgs.

34. See for example Antoine Picon and Jean-Paul Robert, Un Atlas parisien: Le Dessus des cartes (Paris: Éditions du Pavillon de l'Arsenal and Picard, 1999).

35. Blaise Pascal, Pensées, in OEuvres complètes (Paris: Gallimard, Collection de la Pléiade, 1954), 1106. 